\title{
大気污染物質の放出量推定における精度向上に関する研究 STUDY ON IMPROVEMENT OF SOURCE INTENSITY ESTIMATION METHOD FOR AIR POLLUTANT
}

\author{
大 浦理路*1, 金 敏植 ${ }^{* 2}$, 大場良二*3, 加藤 信 介 ${ }^{* 4}$ \\ Masamichi OURA, Minsik KIM, Ryohii OHBA \\ and Shinsuke KATO
}

\begin{abstract}
The purpose of this report is the improvement of the source intensity estimation. Accuracy improvement of source intensity estimation were performed on the following 4 uncertainties. 1) Uncertainty of wind direction was decreased by expanding observation time. 2) Uncertainty of emission height was decreased by removing observation data measured near a source point. 3) Terrain influence was reproduced in modified Gaussian plume model, based on wind tunnel experiment. 4) Meandering effect was reproduced by using the variance of wind direction in the field. It was verified that accuracy was improved and order estimation can be performed by these methods.
\end{abstract}

\section{Keywords : Source intensity estimation, Atmospheric dispersion, Uncertainty 放出量推定，大気拡散，不確かさ}

\section{1. はじめに}

本研究は拡散計算結果と観測結果の残差法に基づく污染物質の放 出量推定における不確かさに起因した精度低減の回避を目的とする。 流体中の拡散現象は污染物質放出量及び境界からの流入濃度を入 力とし、流体中の濃度を出力とする線形応答システム付録であると 言うことができる。従って、システムへの入力に対するその応答は、 入力関数とインパルス応答関数との畳み込み積分によって記述が可 能である。環境工学の分野では熱負荷計算に用いられるレスポンス ファクタ法、音響設計に用いられるインパルス応答積分法として一 般的に利用されている。本研究では、パルス入力(単位放出量)に対す る応答を計算し、畳み込み計算により得られる非定常入力に対する 流れ場の非定常応答を基に放出量推定を行っている。上述のパルス に対する応答は、国外の大気拡散分野等において Transfer Coefficient という言葉で既に浸透しており、本論文中では伝達係数 と呼称することとする。

Chino 5 1)、Katata $5^{22}$ は、2011 年 3 月の福島第一原子力発電 所事故を受け、放出量推定結果を公表している。この推定手法は単 位放出率を仮定した大気拡散計算と環境モニタリングデータの比較 によるものである。その後も Chino ら ${ }^{3}$ は継続的に未利用データの 活用や大気拡散モデルの改善により放出量推定の改善を行っている。
本論文における放出量推定手法は既往の放出量推定手法 1),2) と相 互に補い、緊急時の履行リスクを担保するものである。福島第一原 子力発電所事故では、建屋ならびに原子炉格納容器の損壊という「過 酷事故」のため、建屋から放出された放射性物質の量が不明であった ことや、津波によるモニタリングポストの電源喪失により周辺の放 射線観測データが不足したため、緊急時迅速放射能影響予測ネット ワークシステム (System for Prediction of Environmental Emergency Dose Information：SPEEDI)による放射能強度の試算 を避難計画の策定に活用することができなかった。このため過酷事 故評価における実用的な放出源強度推定手法の開発が求められたの である。

既往の放出量推定手法の課題のいくつかは気象モデルのような広 域的な拡散モデルを利用していることに起因している。そこで本論 文における放出量推定手法 ${ }^{4}$ ) は、近距離域(数 $\mathrm{km}$ 程度以内)の拡散 予測に簡便のために広く利用されている「正規型プリュームモデル」 及び「風洞実験」に利用している。

広域な観測点では、放出量推定に必要な十分な濃度を保持した観 測データを得ることは難しい。そこで、原子力発電所敷地境界付近 の近距離観測データの利用を検討した。東京電力福島第一原子力発 電所事故において、近距離観測データは放出量推定に利用されるこ

\footnotetext{
*1 (秼)日建設計設備設計部 設備設計 ·工修

*2 国立研究開発法人日本原子力研究開発機構 助手·工博

*3 東京大学生産技術研究所 シニア研究員·工博

*4 東京大学生産技術研究所 教授 ·工博
}

Mechanical Engineer, Mechanical and Electrical Design Section, Nikken Sekkei, M.Eng. Research Assoc., Dept. of Architecture, Faculty of Engineering, Japan Atomic Energy Agency, Dr.Eng.

Senior Researcher, Institute of Industry Science, The University of Tokyo, Dr.Eng. Prof., Institute of Industry Science, The University of Tokyo, Dr.Eng. 
とがなかった。これは、既存の気象モデル (SPEEDI など) では $1 \mathrm{~km}$ 以下の空間の解像が難しいためである。発電所敷地境界では、陸側 全風向について観測点が配置されているので、風向が変動しても放 出量のピークを捕らえられる可能性が高い。

本研究の放出量推定手法は、各気象条件に対応した正規型プリュ 一ムモデルの計算結果をデータベース化しておくことで、迅速性お よび実用性を可能とした。気象モデルは広範囲の複雑な物理過程を 解くため、解を得るまでに膨大な時間がかかる。この計算時間を減 じるには莫大な計算資源を投入しなければならない。污染質拡散時 の緊急対応には、迅速かつ非専門家でも扱える実用性が必要である。

気象モデルは計算コストや時間が大変に掛かることや利用できる 観測值が濃度ピークを捕らえていない可能性と言った難点が存在す るが、気象・拡散現象を厳密に解析するため実現象の再現性が高い と言える。これに対し、正規型プリュームモデルは非線形現象であ る排気上昇過程を大気拡散過程とは分離して計算し、計算全体を線 形現象として扱うが、それ故、迅速に解が得られ、利用できる観測 值も濃度ピークを捕らえている可能性が高い。このように、両者の 特性を利用して、複数の放出量推定手法を準備しておくことで、緊 急時の敏速かつ精度良い放出量推定を可能とする。

放出量推定手法の推定精度に関する課題は「拡散モデルの精度」、 「観測データの信頼性」、「観測值と伝達係数の両者間に内在する不 確かさ(Uncertainty)」の 3 点に大別される。

「拡散モデルの精度」は、数值計算の実現象に対する再現精度に 起因する。福島事故後も、気象モデルの改善や乱流モデルの改善 等、多方面において改善が進められている。

「観測值の信頼性」については、放出量推定に使用する観測デー 夕の前処理(時間平均データ処理、Filtering 処理等)を行うことによ って、大幅に放出量推定精度が向上することが分かった ${ }^{4)}$

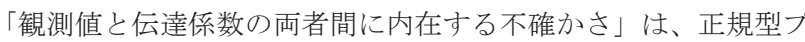
リュームモデル内の気象条件（風向、大気安定度）および拡散パラ メータ(拡散幅、放出源有効高さ)が不確かさを内包しており、大幅 に放出量推定精度が変動することである。

本報では下記の放出量推定精度を向上させるための手法を検討し、 その有効性について検証を行った。

(1)風向の不確かさによる放出量推定精度低減の改善

(2)放出源有効高さの不確かさによる放出量推定精度低減の改善

(3)地形影響のある流れ場における正規型プリュームモデルの精度 向上

(4)正規型プリュームモデルにおける大気安定度の影響の再現

\section{2. 放出量推定手法}

本論文における放出量推定手法 ${ }^{4}$ は、単位放出を仮定した拡散モ デルによる拡散計算結果と観測結果を比較することにより、その誤 差を最小とする放出量を算出する「残差法」と呼ばれるものである。

\section{2-1, 放出量推定計算}

放出位置 $\left(\mathrm{x}_{\mathrm{i},}, \mathrm{y}_{\mathrm{i}}, \mathrm{Z}_{\mathrm{i}}\right)$ 、放出時刻 $\mathrm{t}_{\mathrm{i}}$ における放出量を $\mathrm{Q}_{\mathrm{i}}$ とし、観測位 置 $\left(\mathrm{x}_{\mathrm{k}}, \mathrm{y}_{\mathrm{k}}, \mathrm{Z}_{\mathrm{k}}\right)$ 、観測時刻 $\mathrm{t}_{\mathrm{k}}$ とする時、放出時刻 $\mathrm{t}_{\mathrm{i}}$ に単位量で放出され た污染物質による観測時刻 $\mathrm{t}_{\mathrm{k}}$ の観測值(濃度、沈着率、線量率)を伝 達係数 $\varphi_{\mathrm{ki}}$ とする。また、観測位置 $\left(\mathrm{x}_{\mathrm{k}}, \mathrm{y}_{\mathrm{k}}, \mathrm{Z}_{\mathrm{k}}\right)$ 、観測時刻 $\mathrm{t}_{\mathrm{k}}$ における
実際の計算值を $\mathrm{F}_{\mathrm{k}} \mathrm{k}$ 、観測值を $\mathrm{F}_{\mathrm{k}}$ とし、両者の残差ノルム で定義する。

$$
\pi=\sum_{k}^{N}\left|F^{\prime}{ }_{k}-F_{k}\right|^{2}
$$

ここに、計算值 $\mathrm{F}_{\mathrm{k}}{ }_{\mathrm{k}}$ は次式で表される。

$$
\boldsymbol{F}^{\prime}{ }_{k}=\sum_{i}^{M} \varphi_{k i} \cdot Q_{i}
$$

このாを最小にするように、(3)、(4)で放出量 $\mathrm{Q}_{\mathrm{i}}$ を算出する。

$$
\begin{gathered}
\frac{\partial \pi}{\partial Q_{i}}=0 \\
\sum_{k}^{N} \sum_{j}^{M}\left\{\varphi_{k i} \cdot \varphi_{k j}\right\} Q_{j}=\sum_{k}^{N} \varphi_{k i} \cdot F_{k}
\end{gathered}
$$

上記のような伝達係数の重ね合わせの可能性は前項における流体 中の拡散現象が線形応答システムであると言う論拠によるところで ある。濃度に関する線型性を論拠としたが、沈着率、線量率につい ても濃度と同様に線形であるため、同様の計算により放出量推定が 可能である。

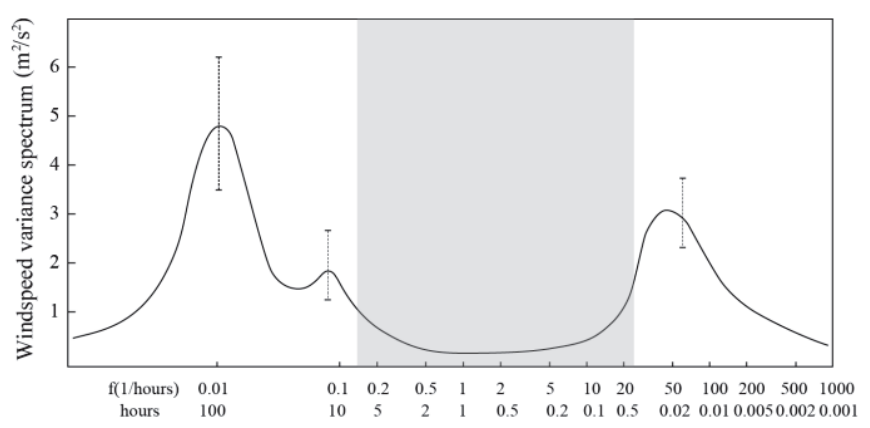

Fig.1 Spectrum of wind speed variance ${ }^{5)}$

次に、正規拡散式の適用対象である気象条件の定常性について、 説明する。我々の生活する大気環境は地球規模の大気の運動が作用 しており、幅広いスケールの渦が合成されたものである。このこと は Fig.1 の Van der Hoven ら 5)にる水平方向風速のエネルギース ペクトル分布からも確認することが可能である。この図において各 3 点 $(0.01,0.1,100$ cycles/hour $)$ の周波数ピークが見られる。最低周 波数帯域ピーク (0.01cycles/hour)は、100 時間周期で顕著な流体運 動があることを示している。この流体運動は気圧変動に起因してお り、ロスビー波のエネルギー伝播により気圧が数日単位で変動する ことに因がある。また、 $0.1 \mathrm{cycles} / \mathrm{hour}$ 近傍の周波数帯域ピークは 10 時間周期で流体運動が盛んであることを示唆している。これは日 射により半日単位で温度変動が生じ、密度効果により上下空気層の 混合が行われるためである。さらに、最高周波数帯域ピーク $(100$ cycles/hour)は、乱流に基づく 1 分間周期の流体運動の変動による ものである。1 cycles/hour 付近に見られる落ち込みはスペクトルギ ヤップと呼ばれ、風速の時間平均值に関して定常性が期待できる。

本研究で使用する観測值は、近距離の発電所周辺のデータ（放出 源及び観測点間の距離が数 $\mathrm{km}$ 程度) であるため、着目する大気拡散 の時間スケールは数分から数時間程度である。このことから、大気 
気流スペクトルの低周波数側(長周期成分) と高周波数側(短周期成 分)は除去することができ、数時間は定常な気象条件が仮定できる。 従って、1 時間毎の風向および風速の平均值を使用すれば、準定常」 仮定の正規型プリュームモデルに基づく放出量の推定が可能である。 準定常仮定に伴い、(4)式は時間項を除去した(5)式に書き換えられ る。但し、 $\mathrm{k}$ は地点に関する変数でもあるため、除去されない。

$$
\sum_{k}^{N} \varphi_{k}^{2} \cdot Q=\sum_{k}^{N} \varphi_{k} \cdot F_{k}
$$

\section{2-2. 正規型プリュームモデル}

正規型プリュームモデル(Gaussian Plume Model)は、点源から放 出された污染質が正規分布するものと仮定し、風速と大気安定度を 基にその空間分布の挙動を計算するものである。煙突および自動車 等からのガス排出の大気環境影響評価を行う際に古くから用いられ ており、原子力施設の放射性ガス拡散評価 ${ }^{6)}$ においても利用されて いる。この場合、拡散濃度は(6)式により表現することが可能である。

$$
C=\frac{Q}{\pi \alpha_{0} U \sigma_{y, p} \sigma_{z, p}} \exp \left\{-\frac{y^{2}}{2 \sigma_{y}^{2}}\right\} \exp \left\{-\frac{H_{e}{ }^{2}}{2 \sigma_{z}^{2}}\right\}
$$

ここで He は放出源有効高さ、 $\sigma_{\mathrm{y}} 、 \sigma_{\mathrm{z}}$ は水平及び鉛直方向の拡散 幅である。放出源有効高さとは排気筒高さに対して排気上昇過程を 考慮した高さのことである。また、拡散幅とは濃度分布の標準偏差 を示しており、Fig.2 に示すように、煙軸からの距離に関する正規分 布として記述される。

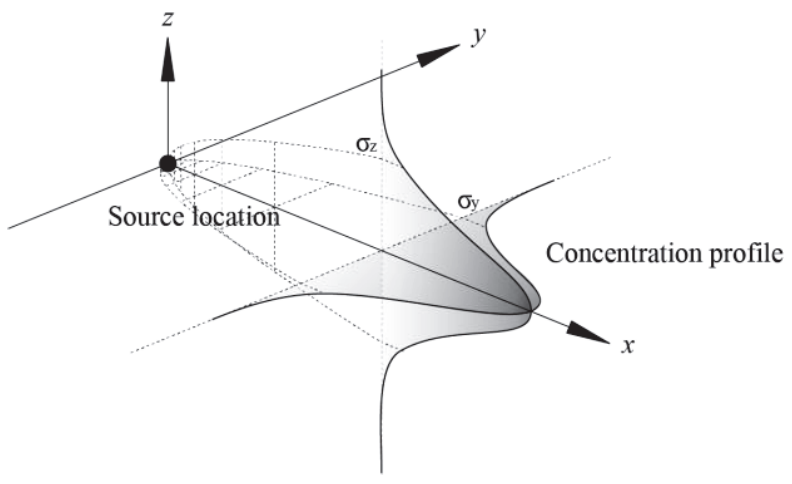

Fig.2 Concept of Gaussian plume model

\section{3. 放出量推定精度向上}

正規型プリュームモデルを利用した放出量推定手法の精度に影響 する主要なパラメータとしては、次の 4 種類の要因が考えられる。

（1）風向：計算に使用する風向角度と野外の風向角度の差

（2）放出源有効高さ：放出箇所が不明な場合

（3）地形影響：地形による有効放出源高さ、拡散幅及び煙軸の変化 （4）大気安定度：大気中の温度分布に起因する乱流拡散現象の変化 放出量推定精度の評価尺度は、(7)式の $\mathrm{Q}^{*} に よ り$ 評価するので、 100\%が正解である。放出量推定精度 $Q *$ *、推定される放出量 $\mathrm{Q}$ と 真值 QTRUE の比により定義する。

$$
Q^{*}=\frac{Q}{Q_{\text {TRUE }}} \times 100(\%)
$$

\section{3-1. 風向の不確かさ}

発電用原子炉施設の安全解析に関する気象指針 6)によれば、気象 観測データの風向は、観測時間は正時前 10 分間の平均風速であり、 16 方位分類により記録されるので、最大で $11.25^{\circ}$ の誤差を含み得 る。また、発電所で観測される風向は、周辺の地形および建物の影 響で、上空風向と異なることも想定される。この風向の不確かさに 起因する放出量推定精度を向上させる対策を検証した。

観測值として発電用原子炉施設安全審査のために実施された東海 第二発電所風洞実験結果(濃度) 注 1) 用いた。風洞実験では、放出源 より風下 $200 \mathrm{~m}-10000 \mathrm{~m}$ 格子状 23 行 24 列 552 点の地表濃度を計 測している。実験条件は原子力学会が制定した風洞実験実施基準 7) に準じて実施されており、繰り返し実験時のばらつきは、10\%以下 であることが確認済みである。

風洞気流条件を Table1 に示す。発電用原子炉施設安全審査用風 洞実験では、地形模型実験結果の煙軸地表濃度分布を安全側で近似

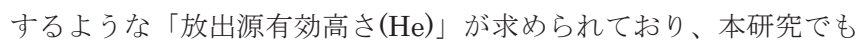

\begin{tabular}{|c|c|}
\hline $\begin{array}{c}\text { Wind speed in wind } \\
\text { tunnel } \\
\text { 風洞風速 }\end{array}$ & $\begin{array}{l}3 \mathrm{~m} / \mathrm{s} \text { in an uniform flow } \\
\text { 一様流中で } 3 \mathrm{~m} / \mathrm{s} \text { とする。 }\end{array}$ \\
\hline $\begin{array}{l}\text { Wind direction of } \\
\text { experiment }\end{array}$ & 11 direction that land is on downwind of 16 direction centered on source \\
\hline 実験風向 & 放出源を中心にした16風向のうち、風下側が陸となる風向について実施する。 \\
\hline $\begin{array}{l}\text { Vertival wind speed } \\
\text { distribution }\end{array}$ & $\begin{array}{l}\text { Shape of vertical wind speed distribution in wind speed boundary layer is }-1 / 7 \text { power } \\
\text { law }\end{array}$ \\
\hline $\begin{array}{l}\text { 鉛直方向 } \\
\text { 風速分布 }\end{array}$ & 風速境界層内部の鉛直方向風速分布の形状を約 $1 / 7$ 乗とする。 \\
\hline $\begin{array}{l}\text { Vertival turbu- lance } \\
\text { intensity distribution }\end{array}$ & $\begin{array}{l}\text { Shape of vertical turbulance intensity distribution in wind speed boundary layer is }-1 / 7 \\
\text { power law }\end{array}$ \\
\hline $\begin{array}{l}\text { 鉛直方向 } \\
\text { 乱流強度分布 }\end{array}$ & 風速境界層内部の鉛直方向乱流強度分布の形状を約 $-1 / 7$ 乗とする。 \\
\hline $\begin{array}{l}\text { Main flow turbu- } \\
\text { lance intensity }\end{array}$ & Main flow turbulance intensity at ground altitude $30 \mathrm{~m}$ in field is $10-16 \%$ \\
\hline $\begin{array}{l}\text { 主流風向 } \\
\text { 乱流強度 }\end{array}$ & 野外の地上高度 $30 \mathrm{~m}$ での主流風向の乱流強度を約 $10-16 \%$ とする。 \\
\hline $\begin{array}{l}\text { Thickness of } \\
\text { baundary layer }\end{array}$ & Ground altitude over $400 \mathrm{~m}$ in field \\
\hline 境界層厚さ & 野外の地上高度 $400 \mathrm{~m}$ 以上とする。 \\
\hline $\begin{array}{l}\text { Atmospheric } \\
\text { stability }\end{array}$ & Vertical plume width is adjusted to range of atmospheric stability C-D \\
\hline 大気安定度 & 鉛直方向拡散幅が大気安定度C-D の範囲になるようにする。 \\
\hline $\begin{array}{l}\text { Condition of gas } \\
\text { dispersion }\end{array}$ & $\Gamma$ shaped stack model can disperse tracer gas horizontally in downwind \\
\hline ガス排出条件 & 風下方向にトレーサ・ガスを水平に放出するГ 型模型排気筒を用いる。 \\
\hline $\begin{array}{l}\text { Scale and range of } \\
\text { model }\end{array}$ & Scale: $1 / 2000$, Range: Downwind $10 \mathrm{~km}$ of source \\
\hline 模型縮尺及び範囲 & 模型縮尺 $1 / 2000$ で、放出源の風下 $10 \mathrm{~km}$ の範囲を再現する。 \\
\hline
\end{tabular}
この He を正規型プリュームモデルの計算に使用した。

Table1 Condition of wind tunnel experiment

風向の不確かさに起因する放出量推定精度の影響を検討するため、 正規型プリュームモデルの濃度分布は、Fig.3 に示すように、実際の 濃度分布に対して、風向が北側に $11.25^{\circ}$ だけ偏向したものと仮定 した。

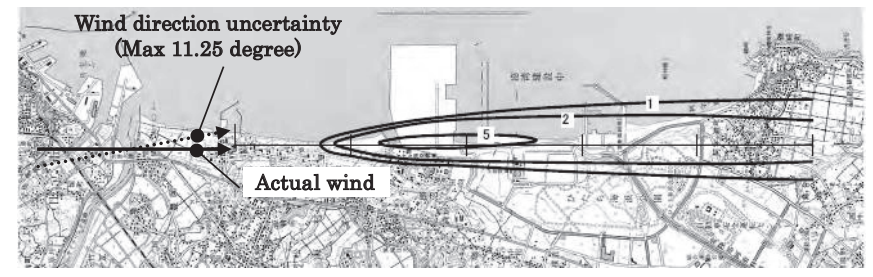

Fig. 3 Wind direction uncertainty (Concentration contour of wind tunnel experiment on Toukai dai-ni nuclear power plant) 
Fig. 4 に東海第二発電所風洞実験と正規型プリュームモデルの煙 軸濃度分布を示す。正規型プリュームモデルが風洞実験をよく近似 しているのが確認できる。Fig.4 では、濃度 $(\mathrm{C})$ に上空風速 $(\mathrm{U})$ を乗 じて、放出量 $(\mathrm{Q})$ で除した正規化濃度 $(\mathrm{UC} / \mathrm{Q})$ の地表煙軸濃度の風下 距離変化を図示している。発電用原子炉安全審查用風洞実験では、 濃度分布を正規化濃度で図示することになっているため、本論文で もこの方法を用いている。

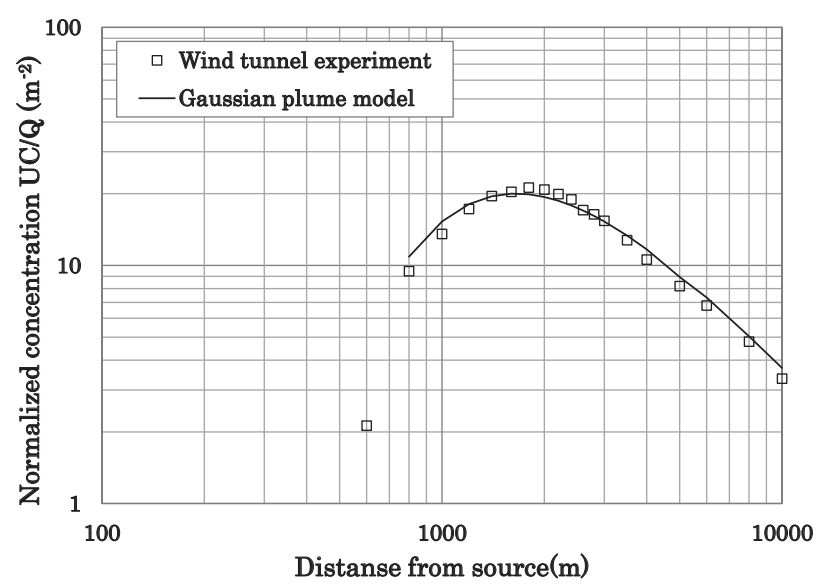

Fig.4 Plume axis concentration distribution of wind tunnel experiment and Gaussian plume model on Toukai dai-ni nuclear power plant

風向が $11.25^{\circ}$ ずれていた場合、煙軸と直角方向の濃度分布は大 きく異なる。 $\mathrm{N}$ 風向風洞実験データ(濃度)を観測值とし、 $\mathrm{N}$ 風向 $11.25^{\circ}$ の拡散計算結果を伝達係数とした場合について、次の 2 種 類の濃度平均時間で、放出量推定計算を実施した。

(1) 3 分間平均濃度 : 風洞実験 $(\mathrm{N}$ 風向)の生データおよび正規型プリ ユームモデル $\left(\mathrm{N}\right.$ 風向 $\left.-11.25^{\circ}\right)$

(2) 1 時間平均濃度: 風洞実験 $(\mathrm{N}$ 風向)データを(8)式で補正した值お よび正規型プリュームモデル(N 風向-11.25)を(8),(9)式で補正し た值

$$
\begin{gathered}
\sigma_{y}^{\prime}=\sigma_{y} \times\left(\frac{t^{\prime}}{t}\right)^{r} \\
C=\frac{Q}{\pi \alpha_{0} U \sigma_{y, p} \sigma_{z, p}} \exp \left\{-\frac{y^{2}}{2 \sigma_{y}{ }^{\prime 2}}\right\} \exp \left\{-\frac{H_{e}{ }^{2}}{2 \sigma_{z}^{2}}\right\}
\end{gathered}
$$

ここで、 $\sigma_{\mathrm{y}}^{\prime}$ は評価時間 $\mathrm{t}$ 'に対する水平方向拡散幅、 $\sigma_{\mathrm{y}}$ は評価時間 $\mathrm{t}$ に対する水平方向拡散幅、 $\mathrm{t}^{\prime}$ は評価時間 $(=60 \mathrm{~min}) 、 \mathrm{t}$ は評価時間 (=3min)、 $\mathrm{r}$ はべき指数 $(0.2-0.5)$ であるが、本論文では $\mathrm{r}=0.5$ とする。

Fig.5 に風向変動の観測時間依存性を示寸。これは実際の野外拡 散実験の気象観測データにおいて、風向 $\left(\sigma_{\theta}\right)$ が観測時間に応じて変 動することを確認 ${ }^{8}$ した観測例である。龺が観測時間の $0.2 \sim 0.5$ に 比例することが確認できる。野外の水平方向拡散幅 $\sigma_{\mathrm{y}}$ は、濃度平均 時間中の風向変動幅に比例するので、濃度平均時間に従い増大寸る。

Fig.6に風下 $2000 \mathrm{~m}$ 地点における観測值である風洞実験濃度分布 (○) と計算值 $(-)$ の相関を示す。Fig.6(a)の 3 分間平均濃度では、風 向角度を $11.25^{\circ}$ だけ偏向させた正規型プリュームモデル計算值は、 観測值 (風洞実験結果) と大きく異なる分布となった。一方、Fig.6(b) の 1 時間平均濃度では、風向角度を $11.25^{\circ}$ だけ偏向させた正規型
プリュームモデル計算值と観測值(風洞実験結果)は、横風方向拡散 幅が拡大した結果、両者が大差ない結果となった。

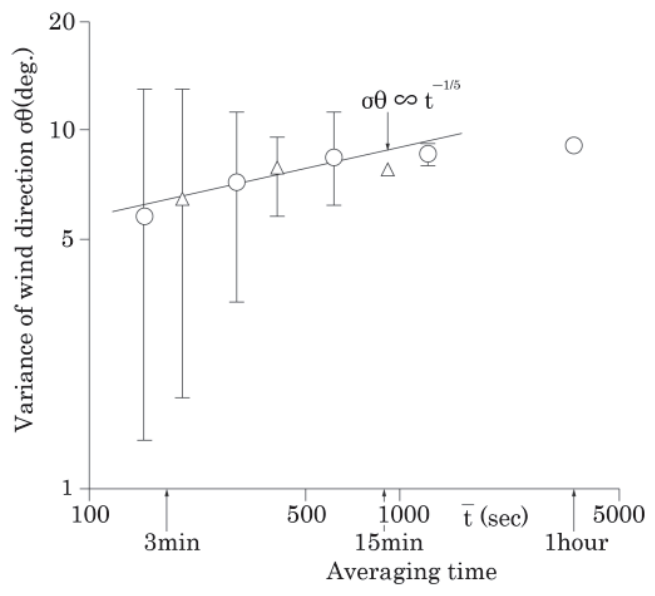

Fig. 5 Observation time dependencies on wind direction variance

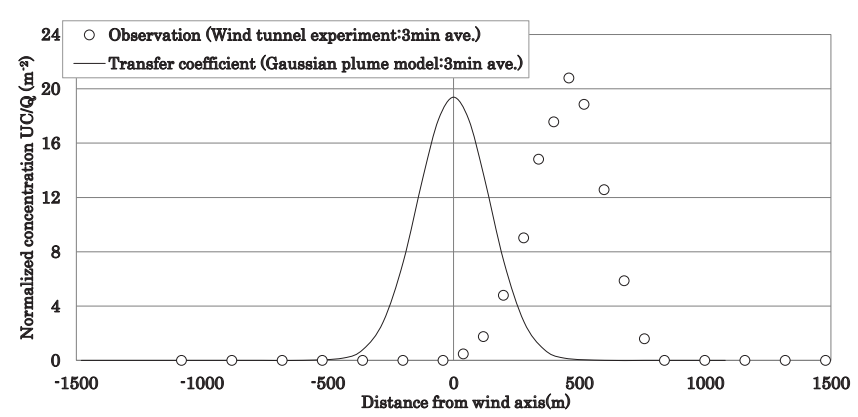

(a) 3 min average

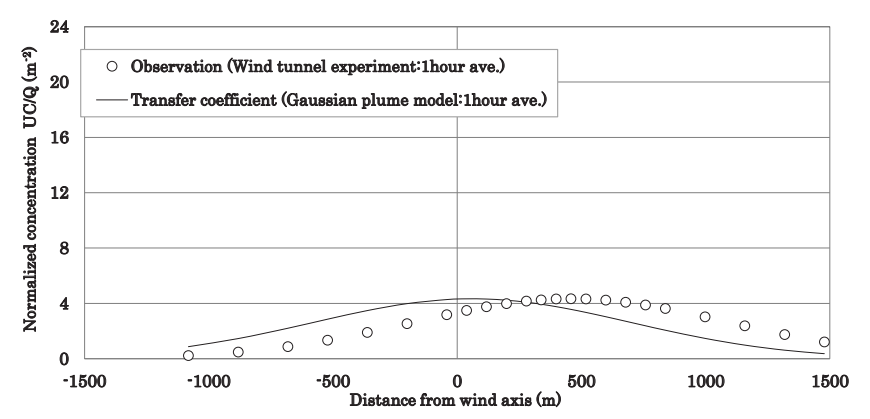

(b) 1hour average

Fig.6 Concentration distribution at $2000 \mathrm{~m}$ downwind on Toukai daini nuclear power plant

Fig.6 (a)の 3 分間平均濃度では、計算值と観測值の濃度ピークは 大幅にずれており、放出量推定精度 $\mathrm{Q}^{*}$ は $3 \%$ となり、推定精度が大 幅に低下した。一方、Fig.6 (b)の 1 時間平均濃度では、計算値と観 測值の横風方向濃度分布が拡大されたために、放出量推定精度 $\mathrm{Q}^{*}$ は $76 \%$ と大幅に改善された。この結果、観測值および拡散計算值を 1 時間平均濃度とすることで放出量推定精度が向上することが明ら かとなった。

以上から、拡散精度を向上させるには、気象観測データから同一 風向の継続時間を考慮して、できる限り平均化時間が長く取れる期 間のデータで放出量推定を行うことが望ましいと考えられる。 


\section{3-2. 放出源有効高さ}

実際の原子力事故時には排気筒高さからの放出に限らず、排気筒 の亀裂や原子炉建屋からの放出も十分に考えられ、放出源有効高さ の推定誤差が内在し得る。Fig.7 に示すように、平常運転時(Normal condition)では建物の巻き込み効果により排気筒近傍で污染質高濃 度域が生じないようある程度以上の排出速度で排気が上方に吹き出 されており、放出源有効高さは実際の排気筒高さより高い。しかし、 事故時(Accidental condition)には吹き出し速度が低下寸るため、 建物後方流の巻き込み効果により排気が排気筒直後で降下し、放出 源有効高さは実際の排気筒高さより低いものとなる可能性がある。 この放出源有効高さの不確かさによる放出量推定精度低減の対策を 検証した。

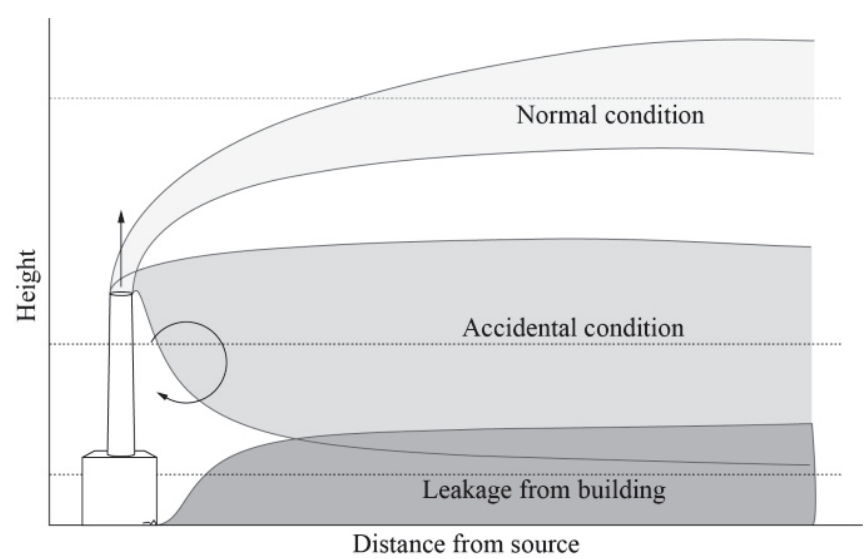

Fig.7 Uncertainty of source effective height

英国 Surrey 大学で実施された風洞実験結果 9)を用いて、放出高 さの不確かさに起因する放出量推定精度への影響を検証した。

Fig. 8 に地表煙軸濃度分布を、Fig.9 に風下距離ごとの濃度分布を 示す。放出源有効高さが一致している場合、正規型プリュームモデ ルにより風洞実験の濃度分布を再現できていることが分かる。放出 高さが相違した場合でも風下 $1000 \mathrm{~m}$ 以遠では濃度分布が大差ない が、風下 $500 \mathrm{~m}$ 以内の放出源近傍では濃度分布に有意な差異がある。

下記の $2 つ の$ 放出源有効高さとして、観測点全点を利用した場合 と風下距離ごとの観測点を利用した場合で、放出量推定を行った。

(1)放出源有効高さ $\mathrm{He}=0 \mathrm{~m}$ : 風洞実験 $(\mathrm{He}=0 \mathrm{~m})$ および正規型プリュ ームモデル $(\mathrm{He}=0 \mathrm{~m})$

(2)放出源有効高さ $\mathrm{He}=20 \mathrm{~m}$ : 風洞実験 $(\mathrm{He}=0 \mathrm{~m})$ および正規型プリュ ームモデル $(\mathrm{He}=20 \mathrm{~m})$

Fig.10 に風下距離ごとの実験データに基づく放出量推定結果を 示す。観測点を全点利用した場合、放出源有効高さに推定誤差が存 在する (2) $\mathrm{He}=20 \mathrm{~m}$ )場合は放出量推定精度が $65 \%$ 程度、過大評価と なった。風下距離ごとに放出量推定を行ったところ、放出源有効高 さに推定誤差が存在する場合でも放出源から離れた風下 $1000 \mathrm{~m}$ 近 傍では、推定精度 $80 \%$ 程度となり、放出量推定精度が改善された。 また、この放出量推定精度低減の対策は建屋影響によるダウンウォ ッシュ発生時における有効高さの相違の場合にも有効であると考え られる。この結果より、放出高度が不明な場合には、近距離の観測 データを使用せず、風下 $1000 \mathrm{~m}$ 以遠の観測データのみを利用する 方法が有効であることが分かった。

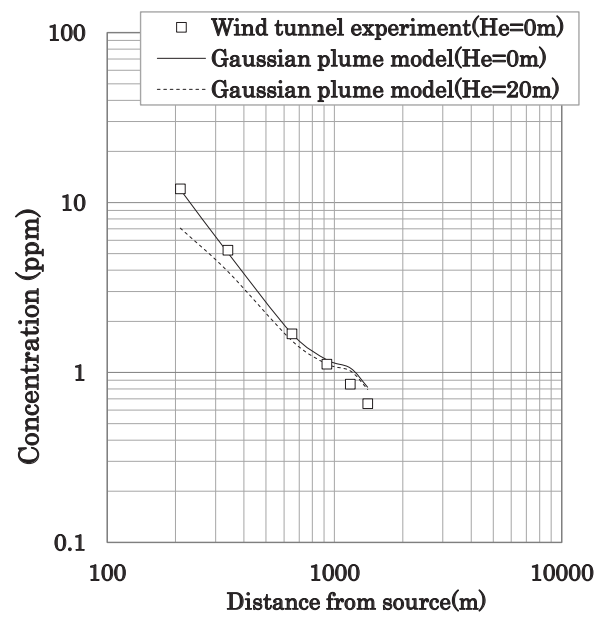

Fig.8 Plume axis concentration distribution of each source effective

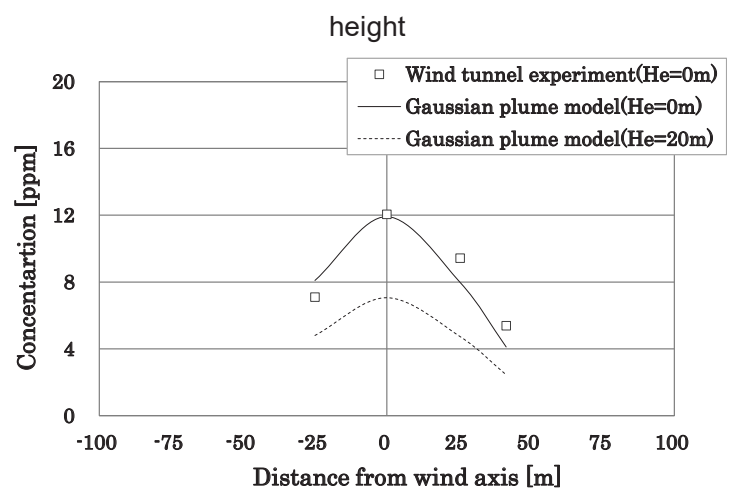

(a) At 210m downwind

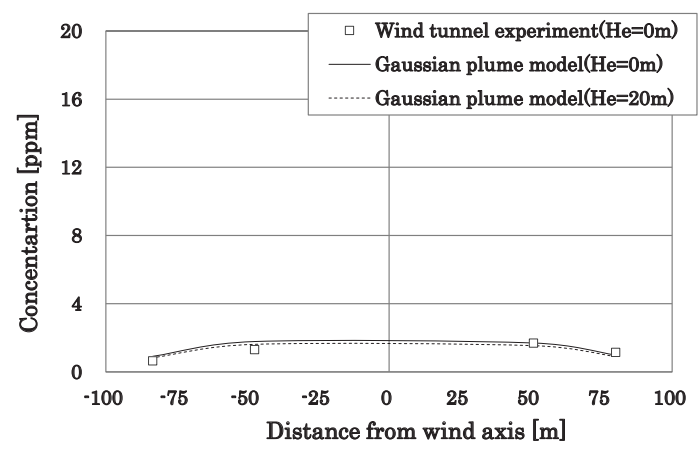

(b) At $650 \mathrm{~m}$ downwind

Fig. 9 Concentration distribution at each downwind distance

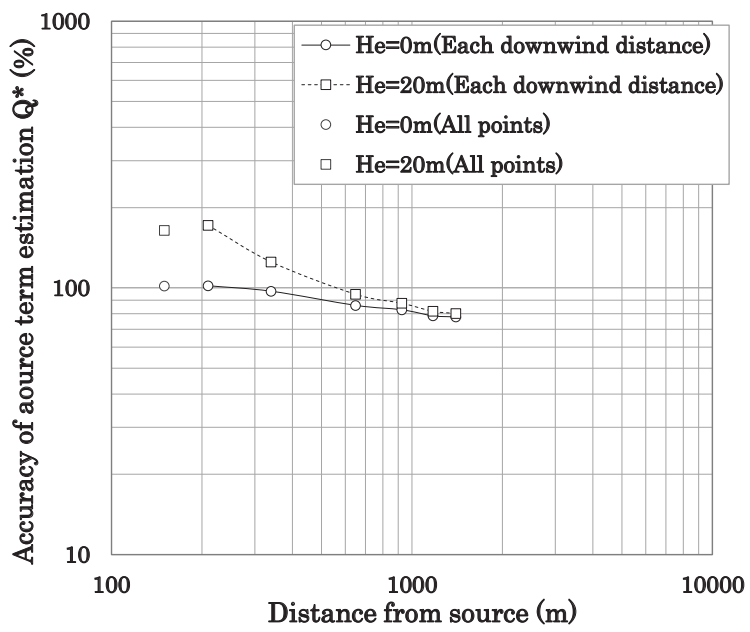

Fig.10 Source intensity estimation of each source effective height 


\section{3-3. 地形影響}

前節の検証の対象であった東海第二発電所は比較的平坦な地形に 位置しており、その地形の影響は小さかった。しかし、複雑地形に おいてはその影響は著しく、拡散現象が平坦地の濃度分布と大きく 異なることが予想される。これに加え、地形影響で上空の風向軸に 対して地表煙軸がずれる偏流が生じる(Fig.11)ことが多い。このた め、複雑地形では、地形影響により濃度分布が大幅に変化するため、 放出量推定精度が低減する可能性がある。この地形影響に対する放 出量推定精度向上を複雑地形に位置する敦賀発電所を対象にした風 洞実験結果注2)を用いて検証を行った。実験条件概要は前節と同一で ある。

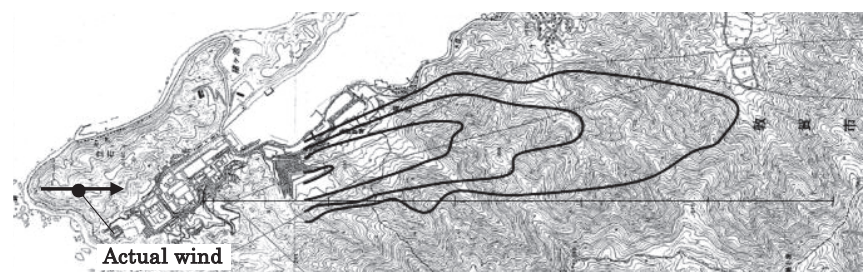

Fig.11 Influence of complex terrain (Concentration contour of wind tunnel experiment on Tsuruga nuclear power plant)

正規型プリュームモデルは平坦地の拡散を対象としているので、 建物および複雑地形の影響は考慮できない。本論文では、正規型プ リュームモデルにおいて建物および複雑地形の影響を考慮できるよ う、放出源有効高さ $\mathrm{He}$ 及び拡散幅 $\sigma$ を風洞実験結果(地表濃度分布) に基づいて修正する手法を開発した。日本国内全ての原子力発電所 において風洞実験結果が公開されているため、これを利用すること で個別の地形影響を考慮した正規型プリュームモデル(以下、修正モ デルと呼称)を作成することが可能である。修正モデルに利用する地 形修正係数は以下の手順でデータ解析を行った。

(1)平地風洞実験で得られた水平方向拡散幅 $\sigma_{\mathrm{y}, \mathrm{p}}$ に合致するように風 下距離 $(\mathrm{X})$ に係数 $(\mathrm{p}, \mathrm{q}, \mathrm{r}, \mathrm{s})$ を乗じ、最小二乗法により $\sigma_{\mathrm{y}, \mathrm{p}}$ を決定する。

$$
\begin{aligned}
\sigma_{y, p} & =\boldsymbol{p} \cdot \boldsymbol{X}^{q} \\
\sigma_{z, p} & =\boldsymbol{r} \cdot \boldsymbol{X}^{s}
\end{aligned}
$$

(2)地形模型風洞実験で得られた水平方向拡散幅 $\sigma_{\mathrm{y}, \mathrm{t}}$ に合致するよう に平地風洞実験の拡散幅 $\sigma_{\mathrm{y}, \mathrm{p}}$ に以下の地形修正係数 (a,b)を乗じ、最 小二乗法により $\sigma_{\mathrm{y}, \mathrm{t}}$ の近似式を求める。(Fig.12)

$$
\sigma_{y, t}=a \cdot \sigma_{y, p}+b
$$

(3)風洞実験で得られた地表煙軸濃度分布に合致するように、以下 の地形地表濃度計算式中の鉛直方向拡散幅 $\mathrm{o}_{\mathrm{z}, \mathrm{t}}$ の地形修正係数 $(\mathrm{c}, \mathrm{d})$ 及び $\mathrm{He}$ を最小二乗法により求める。ここで $\mathrm{a}_{0}$ は上空風速を地上風 速に補正する係数である。(Fig.13)

$$
\begin{gathered}
C=\frac{Q}{\pi \alpha_{0} U \sigma_{y, t} \sigma_{z, t}} \exp \left\{-\frac{H e^{2}}{2 \sigma_{z, t}{ }^{2}}\right\} \\
\sigma_{z, t}=c \cdot \sigma_{z, p}+d
\end{gathered}
$$

Table2 に修正モデルおよび正規型プリュームモデルの地形修正 係数 $(\mathrm{a}, \mathrm{b}, \mathrm{c}, \mathrm{d})$ を示す。 $\sigma_{\mathrm{y}, \mathrm{p}}$ に関する係数は両者共通で $\mathrm{p}=0.24$, $\mathrm{q}=0.85, \mathrm{r}=0.20, \mathrm{~s}=0.78$ であった。敦賀と異なる形では、修正モデ ルも異なるが、日本国内の全原子力発電所については、敦賀と同様 の風洞実験データが公開されているため、同様の手法で個別の地形
影響を考慮した修正モデルを作成し、放出量推定を行うことが可能 である。

Table2 Terrain modified coefficient

\begin{tabular}{c|ccccc} 
& $\mathrm{a}$ & $\mathrm{b}$ & $\mathrm{c}$ & $\mathrm{d}$ & $\mathrm{He}$ \\
\hline Modified plume model & 2.08 & 0 & 1.12 & 0 & 42 \\
Gaussiian plume model & 1 & 0 & 1 & 0 & 144
\end{tabular}

Fig.12 に敦賀発電所風洞実験と修正モデルおよび正規型プリュ 一ムモデルの水平方向拡散幅を、Fig.13 にそれらの煙軸濃度分布 を示す。修正モデルが正規型プリュームモデルよりも、風洞実験を よく近似しているのが確認できる。しかし、煙軸の偏流の影響によ り地表濃度分布が、平坦地と比較して大幅に変化し、放出量推定精 度が低減するものと考えられる。この放出量推定精度の向上を図る ために、風洞実験により得られる地表煙軸の偏流距離 $\left(\mathrm{Y}_{\mathrm{d}}\right)$ を考慮す る。

地形影響による偏流距離を正規拡散モデル内に取り込んだ(15)式 で計算した地表濃度分布で放出量推定計算を行った。

$$
C=\frac{Q}{\pi \alpha_{0} U \sigma_{y, t} \sigma_{z, t}} \exp \left\{-\frac{\left(y-Y_{d}\right)^{2}}{2 \sigma_{y}{ }^{2}}\right\} \exp \left\{-\frac{H_{e}{ }^{2}}{2 \sigma_{z}{ }^{2}}\right\}
$$

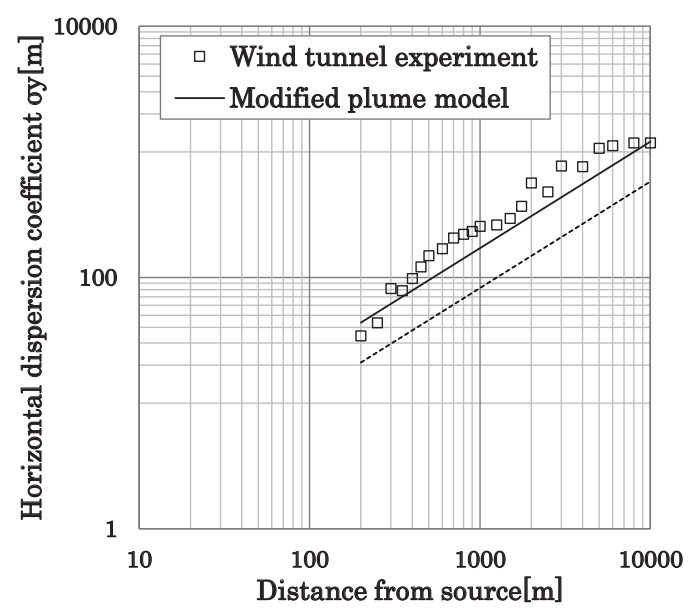

Fig.12 Horizontal dispersion coefficient of wind tunnel experiment, modified plume model and Gaussian plume model

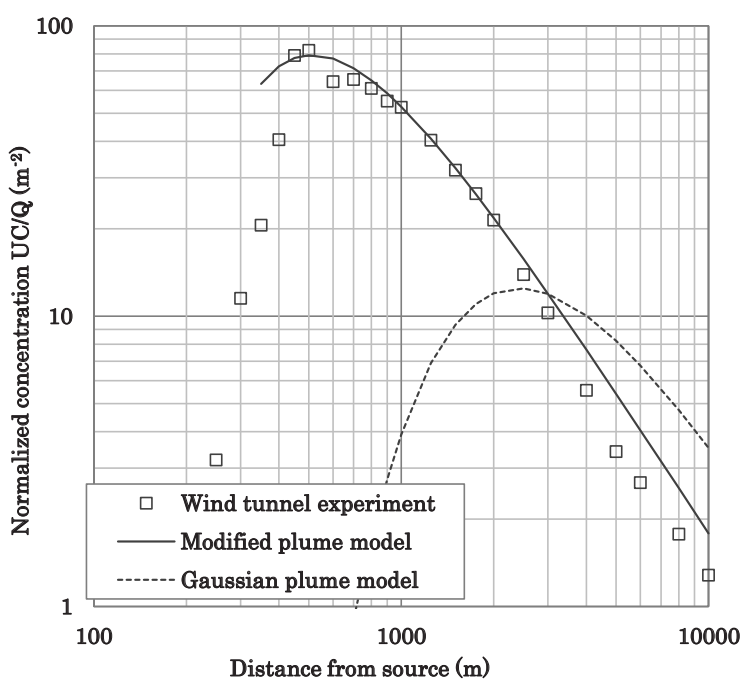

Fig.13 Plume axis concentration distribution of wind tunnel experiment, modified plume model and Gaussian plume model 
Fig. 14 に風下 $2000 \mathrm{~m}$ 地点における観測值である風洞実験濃度分 布 $(○)$ と計算值 $($ 一)の相関を示す。Fig.14 (a)の拡散幅、有効高さお よび偏流変化無しにおいて計算值は観測值と濃度分布に大きなずれ が生じている。放出量推定精度 $\mathrm{Q} *$ は $26 \%$ となった。Fig.14 (b)の 拡散幅、有効高さおよび偏流変化有りにおいては、観測值と計算值 の濃度分布が、概祖一致しているので、放出量推定精度 $\mathrm{Q}^{*}$ は $81 \%$ と大幅に改善された。上記の結果より複雑地形における拡散幅、有 効高さおよび偏流変化考慮の有効性が明らかとなった。

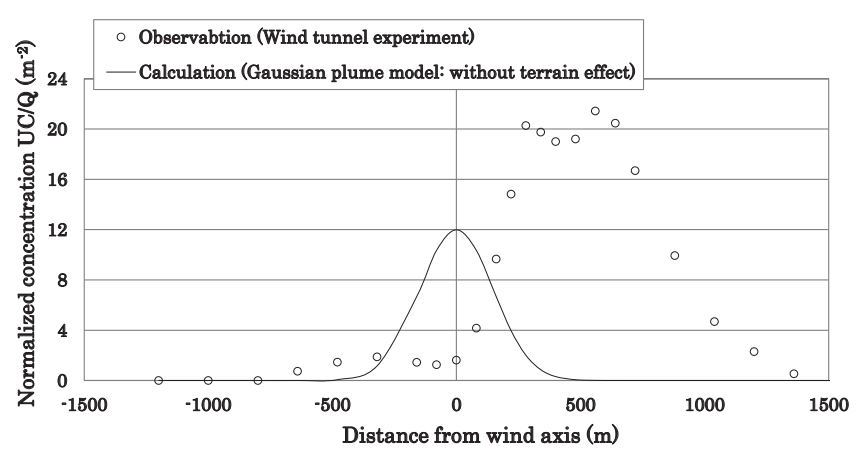

(a) Gaussian plume model without terrain effect

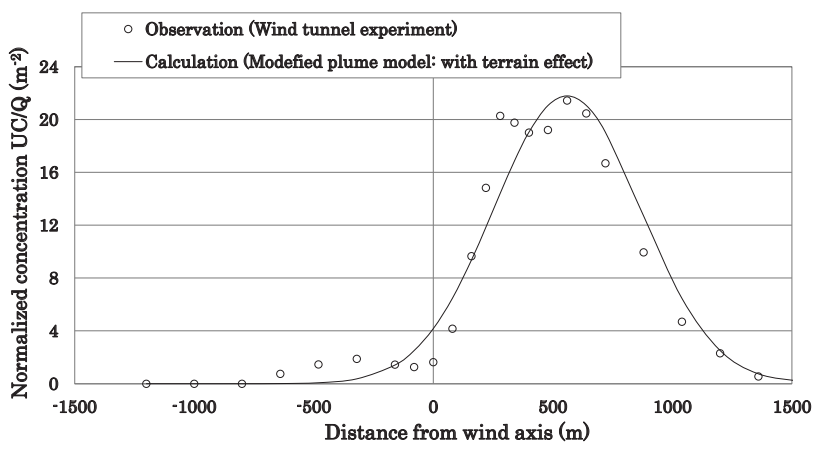

(b) Modified plume model with terrain effect

Fig.14 Concentration distribution at 2000m downwind on Tsuruga nuclear power plant

\section{3-4. 大気安定度}

大気安定度とは、力学的、熱力学的に平衡状態にある大気に微小 擾乱を発生させた際の振る舞いを記述する指標であり、擾乱が減衰 し、平衡状態に戻る場合を安定、擾乱が増幅し、平衡状態に戻らな い場合を不安定と分類する。風洞実験では、一様な温度分布の中立 条件で実験するが、実際の大気拡散現象では、高度方向の温度分布 変化に起因して、強不安定 $(\mathrm{A})$ から強安定 $(\mathrm{F})$ までの大気安定度が出 現し、拡散幅が大きく変動する。

Pasquill ら 10)により提案された大気安定度別拡散幅を Fig.15に 示す。原子炉施設の大気拡散評価では、正規型プリュームモデルの 放出源有効高さ $(\mathrm{He})$ を中立安定度の風洞実験結果から決定し、この He を固定して全安定度の拡散幅を Fig. 15 に従って変化させる方法 によって、年間 8760 時間の大気拡散評価を行うことが発電用原子 炉施設に関連する安全解析の気象指針に規定されている。筑波山周 辺における野外拡散実験および風洞実験を用いて、この放出源有効 高さ $(\mathrm{He})$ を用いる方法により放出量推定計算を行った。

筑波山周辺の野外拡散実験は、1989 年および 1990 年に原子力研 究所(現在の原子力研究開発機構)によって実施され、詳細な観測デ
一タが報告書 ${ }^{11)}$ として公開されており、国内では数少ない野外拡散 実験例である。Fig.16 に筑波山周辺の野外拡散実験の地表濃度分布 観測結果を示す。筑波山周辺の野外拡散実験は濃度平均時間が 30 分 間である。
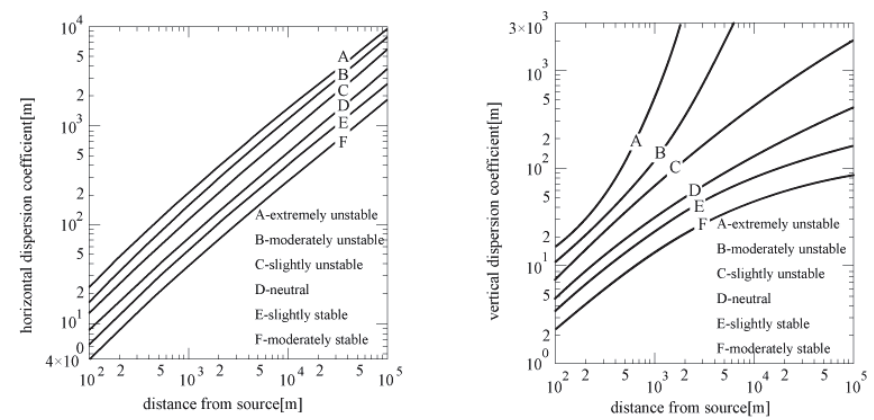

Fig.15 Pasquill-Gifford figure ${ }^{10)}$

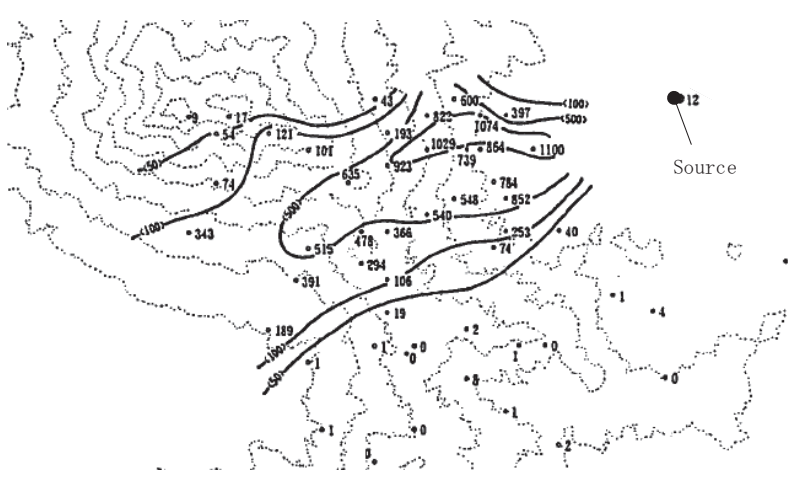

(a) Run No. 89-3 (D : Neutral)

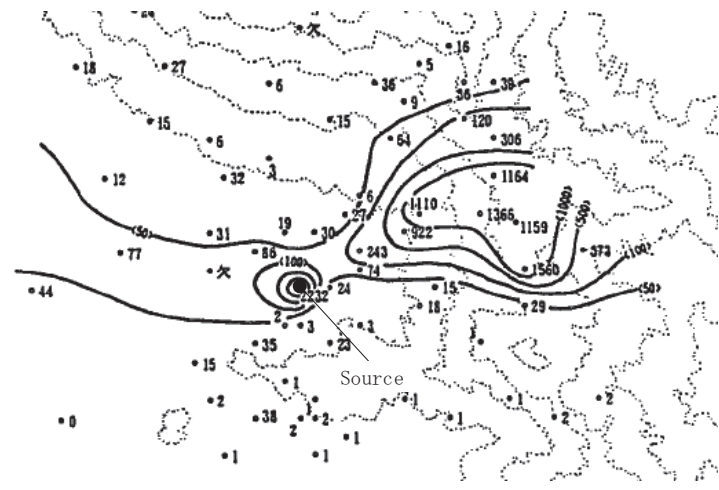

(b) Run No. : 90-5 (F : Stable)

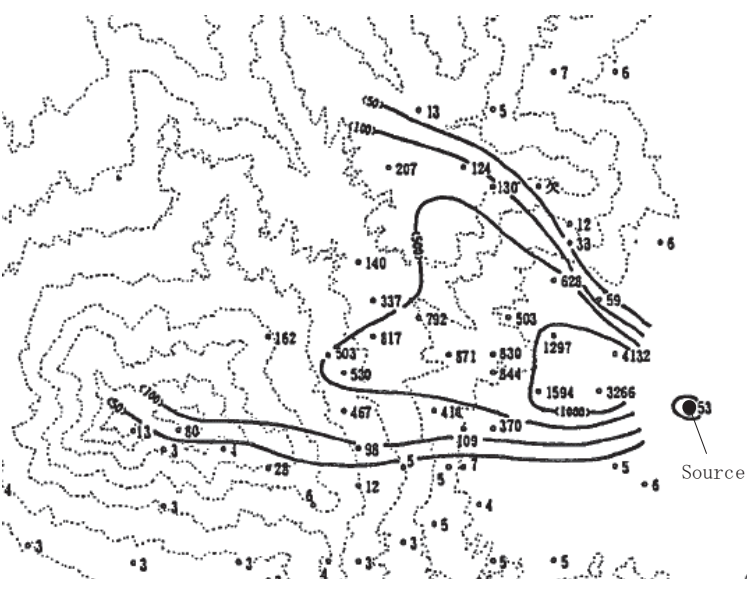

(c) Run No. 90-8 (B : Unstable)

Fig.16 Contour map of concentration 


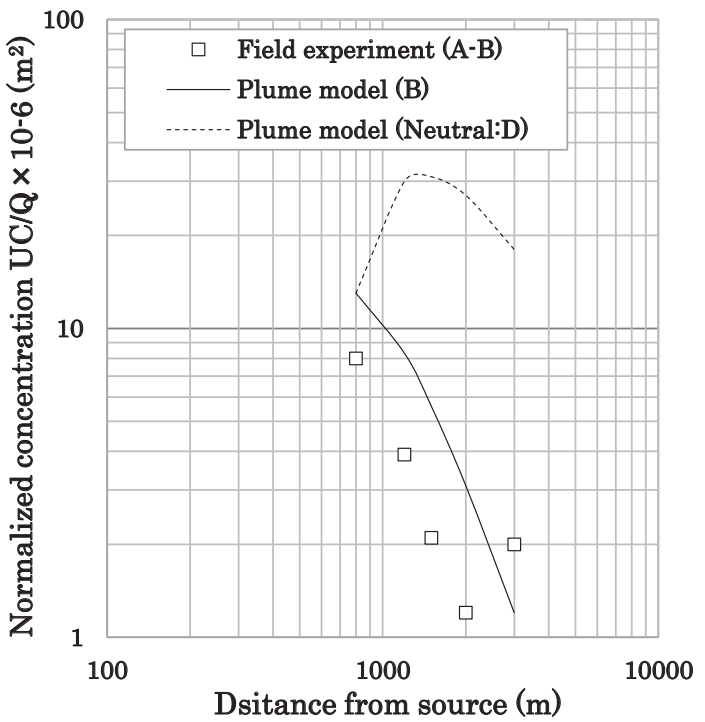

(a) Run No.89-7 (slightly unstable : C)

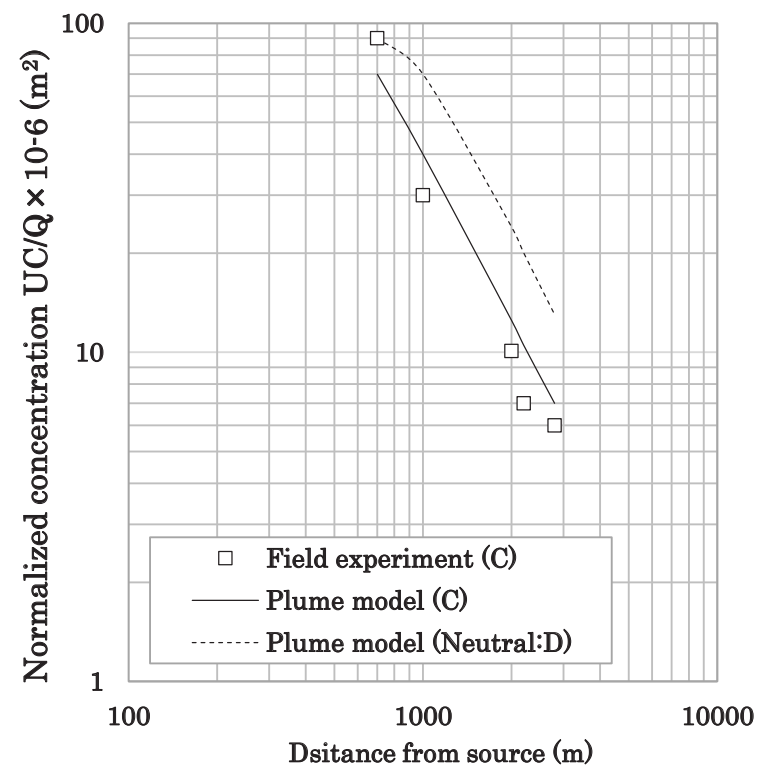

(b) Run No.90-8 (extremely unstable : A-B)

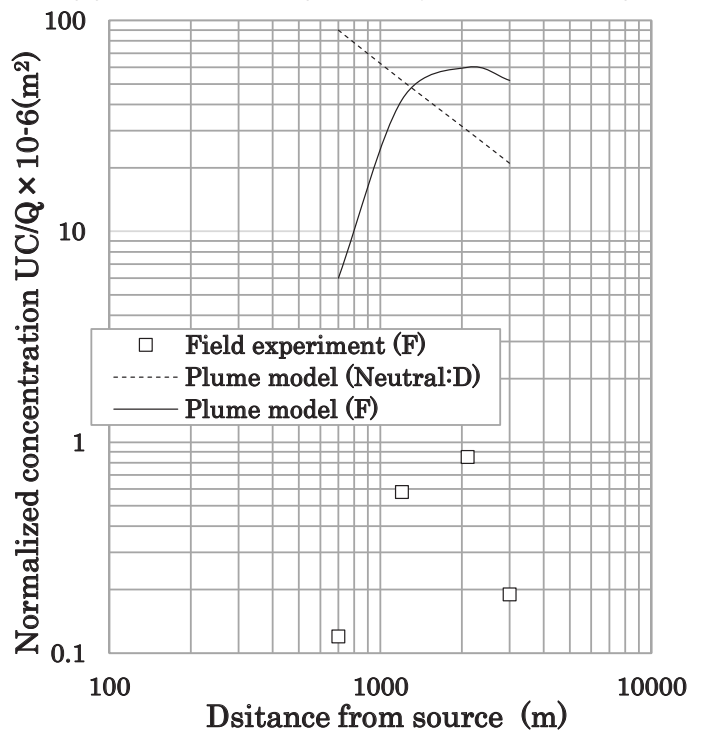

(c) Run No.90-5 (moderately stable : F)
正規型プリュームモデルの計算は日本原子力研究所による風洞実 験から求めた放出源有効高さ 11$)$ 基づく。当報告は筑波山周辺の地 形模型を用いた風洞実験から求めた放出源有効高さを用いて正規型 プリュームモデルで計算した結果と現地拡散試験の結果を比較する ことにより放出源の有効高さを用いた被ばく評価法の妥当性につい て確認を行ったものである。本論文では以下のような代表的な野外 拡散実験 3 ケースについて、正規型プリュームモデル内の拡散幅を 次の 2 種の大気安定度により変化させ、放出量推定を行った。 (1)野外拡散実験と同じ大気安定度で計算 (2)風洞実験と同じ中立の大気安定度(D)で計算

Fig.17 に野外拡散試験と正規型プリュームモデルの地表煙軸濃 度分布比較を示す。中立時(Run No. 89-3)および不安定時(Run No. 90-8)では、正規型プルームモデルの拡散幅を大気安定度別に変化さ せることで濃度分布がほぼ一致している。しかし、強安定時(Run No. : 90-5)には、正規型プルームモデルが観測值よりも、約 1 桁、 過大評価となっている。この原因は、Run No. : 90-5 の気象条件(安 定時かつ弱風）では、風向変動が中立時よりも大きくなるため、平均 時間補正係数が前述の(11)式とは異なるためと考えられる。この対 策として、米国原子力規制委員会(US-NRC)は事故時の安全解析指 針 NUREG 1.14512)において Fig.18 に示すような補正係数 M (Correction Factor)を設定している。

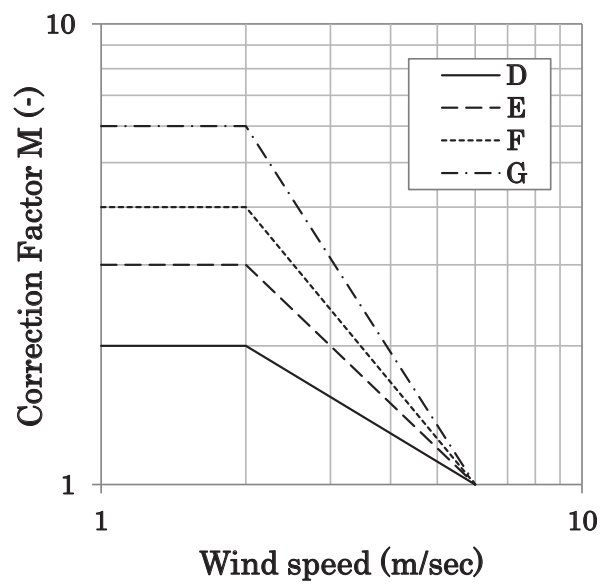

Fig.18 Correction factor M of NUREG 1.145 ${ }^{12}$ )

日本の発電用原子炬施設の安全解析に関連する気象指針では事故 時の被ばく評価結果が安全側となるよう、米国原子力規制委員会に よる補正係数 $\mathrm{M}$ は使用されていない。本論文では放出量推定精度 を向上させるために、安定時について野外で観測された Table3 の 風向変動幅 $\left(\sigma_{\theta 30}\right)$ に基づく(16)式の補正係数 $\mathrm{M}$ を用いて、煙軸濃度 の修正を施した。ここで $\sigma_{\mathrm{y} 3}$ は Fig.17 の風下距離 $1000 \mathrm{~m}$ における 水平拡散幅 $\sigma_{\mathrm{y}}$ である。この補正結果は Fig.19 に示すように、正規 型プリュームモデルと観測值がほぼ一致する結果となった。

$$
\begin{gathered}
M=\frac{\sigma_{\theta 30}}{\sigma_{\theta 3}} \\
\sigma_{\theta 3}=\frac{180}{\pi} \cdot \sigma_{y 3} \cdot 1000
\end{gathered}
$$

Fig.17 Plume axis concentration distribution for atmospheric stability 
Table3 Correction factor $\mathrm{M}$ at moderately stable

\begin{tabular}{c|c|c|c|c|c|c}
\multirow{2}{*}{ Run No. } & \multirow{2}{*}{ Stability } & \multicolumn{2}{|c|}{$\begin{array}{c}\text { Vertical dispersion } \\
\text { coefficient (m) }\end{array}$} & \multicolumn{2}{|c|}{$\begin{array}{c}\text { Variance of wind } \\
\text { direction (degree) }\end{array}$} & \multirow{2}{*}{ Correcttion factor M } \\
\cline { 3 - 6 } & & oy3 & oy30 & $\sigma \theta 3$ & $\sigma \theta 30$ & \\
\hline $90-5$ & F & 30.0 & 1617.9 & 1.7 & 92.7 & 53.93
\end{tabular}

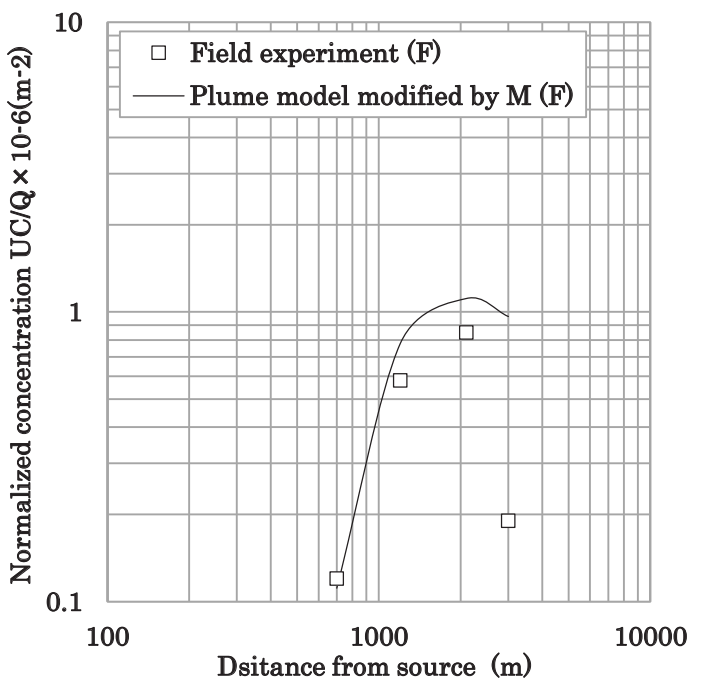

Fig.19 Plume axis concentration distribution of observation values and Plume model modified by Correction factor $M$

Table4 に放出量推定結果を示す。正規型プリュームモデルの大気 安定度を実気象の大気安定度に合わせて補正係数を乗じることで、 安定時の放出量推定精度が、123\%に向上した。福島第一原子力発電 所事故のような原子力緊急時の放出量推定は、1 時間平均值の Order estimation が目標とされており、この結果は十分実用に堪え 得る結果だと言える。

Table4 Source intensity estimation of each atmospheric stability, where the correct estimation is $100 \%$

Field experiment $\quad$ Stability of plume model Run No. Stability (1) Same as field experiment (2)Neutral

\begin{tabular}{cc|cc}
$89-7$ & $\mathrm{C}$ & 123 & 84 \\
$90-8$ & $\mathrm{~A}-\mathrm{B}$ & 32 & 0.09 \\
$90-5$ & $\mathrm{~F}$ & 59 & 0.003
\end{tabular}

\section{5. まとめ}

本研究によって、次のことが確認された。

(1)同一風向の継続時間を考慮し、平均化時間を延長することで、放 出量推定精度低下を低減することが可能であることが確認された。 (2)放出源有効高さの不確かさによる放出量推定精度低下は、放出源 近傍のデータを除くことで対策が可能であることが確認された。

(3)複雑地形よる放出量推定精度の低減は風洞実験結果に基づく修正 正規型プリュームモデルを用いることで対策が可能であることが確 認された。

(4)大気安定度による放出量推定精度の低減は大気安定度別に正規型 プリュームモデル内の拡散幅を変化させることで、対策が可能であ ることが確認された。
謝辞

本研究の一部は、文部科学省原子力基礎基盤戦略研究イニシアテ イブにより実施された「原子力発電所事故時の放出量及び再飛散量 推定手法の高度化に関寸る研究」の成果である。また、本研究では、 日本原子力発電株式会社から、提供された風洞実験データを使用し た。

\section{付録：拡散方程式の線形性}

濃度輸送方程式は、污染発生量 $\mathrm{r}$ が $\alpha$ 倍になれば、濃度 C が $\alpha$ 倍になるこ とが式(1)から明らかであり、污染質発生量 $\mathrm{r}$ が 0 の状態で、濃度 C が境界か らの $\alpha$ 流入濃度に比例した濃度分布になることも明らかである。

$$
\frac{\partial \alpha C}{\partial t}+U_{i} \frac{\partial \alpha C}{\partial x_{i}}=\frac{v}{S c_{t}} \nabla^{2} \alpha C+\alpha \mathrm{r}
$$

更に、污染質発生量 $r_{A}$ に対応寸る濃度を $C_{A} 、$ 污染質発生量 $r_{B}$ に対応寸る濃 度を $\mathrm{C}_{\mathrm{B}}$ とした時、次のように表現される。

$$
\begin{aligned}
& \frac{\partial C_{A}}{\partial t}+U_{i} \frac{\partial C_{A}}{\partial x_{i}}=\frac{v}{S c_{t}} \nabla^{2} C_{A}+r_{A} \\
& \frac{\partial C_{B}}{\partial t}+U_{i} \frac{\partial C_{B}}{\partial x_{i}}=\frac{v}{S c_{t}} \nabla^{2} C_{B}+r_{B}
\end{aligned}
$$

上式の足し合わせを行うと、下式のようになる。

$$
\frac{\partial\left(C_{A}+C_{B}\right)}{\partial t}+U_{i} \frac{\partial\left(C_{A}+C_{B}\right)}{\partial x_{i}}=\frac{v}{S c_{t}} \nabla^{2}\left(C_{A}+C_{B}\right)+\left(r_{A}+r_{B}\right)
$$

以上の性質から、発達した流れ場は、污染質発生量 $\mathrm{r}$ 及び境界からの流入 濃度を入力とする濃度に関する線形応答システムである ${ }^{21)}$ ということができ る。

\section{参考文献}

1) Masamichi Chino, Hiromasa Nakayama, Haruyasu Nagai, Hiroaki Terada, Genki Katata and Hiromi Yamazawa.: Preliminary estimation of release Amounts of 131I and 137Cs accidentally discharged from the Fukushima Dai-ichi nuclear power plant into the atmosphere, Journal of Nuclear Science and Technology Vol.48 No.7 pp.1129-1134, 2011

2) Genki Katata, Masakazu Ota, Hiroaki Terada, Masamichi Chino and Haruyasu Nagai.: Atmospheric discharge and dispersion of radionuclides during the Fukushima Dai-ichi nuclear power plant accident -Part.1 Source term estimation and local-scale atmospheric dispersion in early phase of the accident-", Journal of Environmental Radioactivity 109 pp.103-113, 2012

3) Hiroaki Terada, Genki Katata, Masamichi Chino and Haruyasu Nagai.: Atmospheric discharge and dispersion of radionuclides during the Fukushima Dai-ichi nuclear power plant accident -Part. 2 Verification of the source term and analysis of regional-scale atmospheric dispersion, Journal of Environmental Radioactivity 112 pp.141-154, 2012

4) Minsik Kim, Shinsuke Kato, Ryohji Ohba and Masamichi Oura.: A source term estimation method for a nuclear accident using atmospheric dispersion models, International Journal of Environmental Pollution, DOI:

http://dx.doi.org/10.1504/IJEP.2015.076582, 2015 (accessed 2015.4.7)

5) I. Van der Hoven.: Power spectrum of horizontal wind speed in the frequency range from 0.0007 to 900 cycles per hour, Journal of Meteorology, 14, pp.160-164, 1956

6) Nuclear Safety Commission, Meteorology guideline for Nuclear Power Facilities Safety Analysis, 1982 (in Japanese) 原子力安全委員会, :発電用原子炉の安全解析に関する気象指針, 1982

7) Atomic Energy Society of Japan, :Code for Wind Tunnel Experiments to Calculate the Effective Height of Emitting Source for Nuclear Power Facilities Safety Analysis, 2009 (in Japanese) 
日本原子力学会, 日本原子力学会標準 発電用原子炉施設の安全解析にお ける放出源の有効高さを求めるための風洞実験実施基準, AESJ-SC-P003, 2010

8) Ryohji Ohba, Nobuhiro Ukeguchi, Shinji Kakishima and B. Lamb.: Wind tunnel experiment of gas diffusion in stably stratified flow over a complex terrain, Proceedings of the 2nd International Conference on Atmospheric Sciences and Application to Air Quality 24 pp.1987-2001, 1990

9) A. C. Rudd, A. G. Robins, J. J. Lepley and S. E. Belcher.: An inverse method for determining source characteristics for emergency response applications, Boundary-Layer Meteorol, 2012

DOI: $10.1007 / \mathrm{s} 10546-012-9712-y$

10) F.A. Pasquill: Atmospheric Diffusion, 2nd ed., Halstead Press- Willey, 1974.

11) Japan Atomic Energy Research Institute, Effective Stack Heights Obtained from Wind Tunnel and Atmospheric Diffusion Experiments, 2001 (in Japanese) (accessed 2015.9.12)

日本原子力研究所, 風洞及び野外拡散試験から求めた放出源有効高さ, JAERI-Tech 2001-034, 2001
http://jolissrch-inter.tokai-sc.jaea.go.jp/pdfdata/JAERI-Tech-2001034.pdf

12) US-NRC.: Atmospheric dispersion models for potential accident consequence assessments at nuclear power plants, Regulatory guide1.145, 1979

注

注 1) Mitsubishi Heavy Industries Ltd. Technical Headquarters, Nagasaki Research and Development Center.: Report on wind tunnel experiments of atmospheric dispersion for Tokai Daini power station, 2013, (in Japanese, disclosed at National Diet Library) 三菱重工業株式会社技術本部長崎研究所, 東海第二発電所風洞実験大気拡 散風洞実験報告書, 2013(国立国会図書館で公開)

注 2) Mitsubishi Heavy Industries Ltd. Technical Headquarters,

Nagasaki Research and Development Center.: Report on wind tunnel experiments of atmospheric dispersion for Tsuruga power station, 2009, (in Japanese, disclosed at National Diet Library)

三菱重工業株式会社技術本部長崎研究所, 敦賀発電所 3,4 号機風洞実験報 告書, 2009（国立国会図書館で公開） 


\title{
STUDY ON IMPROVEMENT OF SOURCE INTENSITY ESTIMATION METHOD
} FOR AIR POLLUTANT

\author{
Masamichi OURA ${ }^{* 1}$, Minsik KIM ${ }^{* 2}$, Ryohji OHBA ${ }^{* 3}$ \\ and Shinsuke KATO*4

\footnotetext{
${ }^{* 1}$ Mechanical Engineer, Mechanical and Electrical Design Section, Nikken Sekkei, M.Eng.

${ }^{* 2}$ Research Assoc., Dept. of Architecture, Faculty of Engineering, Japan Atomic Energy Agency, Dr.Eng.

${ }^{* 3}$ Senior Researcher, Institute of Industry Science, The University of Tokyo, Dr.Eng: ${ }^{* 4}$ Prof., Institute of Industry Science, The University of Tokyo, Dr.Eng.
}

The purpose of this report is the improvement of the source intensity estimation based on a minimal residual method using observed and calculated data of concentration, radiation dose and so on.

This source intensity estimation method uses short range observed data (e.g. a few $\mathrm{km}$ ) and calculated results of Gaussian plume model that is suitable for short range dispersion calculation. In Fukushima Dai-ichi nuclear power plant accident, short range observed data had not been used for source intensity estimation, because it's difficult for the Emergency response model (named SPEEDI) to resolute spaces of calculation region with less than $1 \mathrm{~km}$.

The accuracy of source intensity estimation significantly decreases due to several uncertainties. The 4 uncertainties of the source intensity estimation were investigated and their improvements were verified.

1) Uncertainty of wind direction was decreased by expanding observation time of concentration.

2) Uncertainty of emission height was decreased by removing observation data measured near from source point.

3) Terrain influence was reproduced in Gaussian plume model by modifying plume widths, effective source height and displacement of plume axis, based on wind tunnel experiment.

4) Meandering effect of Atmospheric stability on lateral plume width was reproduced in Gaussian plume model by using the observed data on fluctuation of wind direction in the field under a stable atmospheric stability.

According to "Meteorology guideline for nuclear power facilities safety analysis", wind directions of meteorological observation data were categorized into 16 directions and concentration calculated from a mean value for few minutes. Consequently, the wind direction can include an error. The uncertainty caused by wind direction error was improved by using data on observation, and dispersion simulation that calculated a mean value for 1 hour. Because of lateral dispersion width is proportional to the variance of wind direction and increase with observation time, concentration distribution is smoothed for 1 hour, more than few minutes.

When a release from a nuclear reactor building is imagined in a severe accident, an uncertainty of release height can be inherent. The ground-level concentration distribution does not depend on the release height over the downwind distance of more than $1000 \mathrm{~m}$, but they depend on it in vicinity of the source. The uncertainty due to release height was improved by not using data on observation and dispersion simulation in vicinity of source.

Because Gaussian plume model was developed for the dispersion calculation on flat terrain, it's not able to consider an influence of building and complex terrain. A new measure that modifies an effective source height, plume widths and plume axis based on wind tunnel experiment was developed in this research. The accuracy of source intensity estimation was greatly improved by this new measure.

Actual atmospheric stability appears from strong stable to strong unstable in the field, but wind tunnel experiment have been done usually under neutral stability condition. The plume width used for the calculation is selected based on Pasquill-Gifford chart corresponding to atmospheric stability. In the present paper, lateral plume width and concentration of plume axis are modified by using a correction factor $\mathrm{M}$ based on a field experiment. It was confirmed that the source intensity can be estimated by the accuracy of one order under non-neutral stability for the field dispersion experiment conducted around Mt. Tsukuba.

It was verified that accuracy was improved and order estimation can be performed by these methods. These methods can be applicable for the operational use, because order estimation is target at a nuclear power accident. 